\title{
Analysis of the intensity of post-vaccination immunity to acute respiratory viral infections of cattle
}

\author{
E.V. Maksimova*, E.S. Klimova, E.A. Merzlyakova, and L.L. Maksimov \\ FSBEI HE Izhevsk SAA, Izhevsk, Russia
}

\begin{abstract}
Of the acute respiratory viral infections in the farms of the Udmurt Republic, parainfluenza-3, respiratory syncytial infection, infectious rhinotracheitis, viral diarrhea are the most common. For the prevention of these cattle diseases, the inactivated combined vaccine Kombovak and Kombovak R. is used. Despite the widespread use of this vaccine, there is an ambiguous situation in the farms of UR and the percentage of ARVI incidence is extremely variable. Along with general economic factors, this can be explained using different schemes for the use of the vaccine. The work was carried out in the conditions of an industrial livestock complex located in the Uvinsky district of the Udmurt Republic. During the period of the work, 1,383 heads of cattle vaccinated with the Kombovak-R vaccine were monitored. Laboratory tests were carried out in the BI UR "Udmurt Veterinary Diagnostic Center" in the city of Izhevsk and LLC "Independent Veterinary Laboratory "Chance-Bio" in the city of Moscow. Determination of immunity intensity and retrospective serological diagnosis of ARVI was carried out by examining paired blood serum samples. Blood serum samples were taken from clinically healthy cows at the 6th month of pregnancy, i.e. at the end of the inter-vaccination period, as well as from unvaccinated calves with a live weight of $50-55 \mathrm{~kg}$ at the age of 17-18 days and after 21 days, respectively. When studying the preservation of post-vaccination immunity in cows, it was found that only two out of five studied animals have a protective level of antibodies to acute respiratory viral infections by the end of the inter-vaccination period. Serological screening of calves showed that antibodies to the pathogens of IRT, VD, RSI and PI-3 were determined in all samples. nevertheless, the titers of antibodies to ARVI pathogens differed significantly.
\end{abstract}

\section{Introduction}

The most urgent issue of infectious pathology in industrial animal husbandry is the widespread of viral diseases of cattle belonging to the group of acute respiratory diseases [12]. The causative agents of these diseases have a pronounced tropism to the cells of the external mucous membranes of the animal body, which, coupled with a high concentration

\footnotetext{
* Corresponding author: lenamakssimova@mail.ru
} 
of animals in a limited area, provides a high contagiousness of diseases and the formation of a stationary unfavorable focus $[1,3]$.

Studies of Russian and foreign authors have shown that pathogens of acute respiratory viral infections affect cattle without age, sex, and breed restrictions, especially young cattle under the age of 3 months are susceptible to them [2, 4-6]. At the same time, as a rule, in this age group the disease manifests clinically, whereas the animals of the breeding stock are either carriers or are ill in a latent form.

According to the experience of many years of research by various authors, the leading condition for reducing the intensity of the epizootic situation for ARVI diseases in cattle and reducing economic losses is the creation of programs for comprehensive protection of livestock from these infections, in which a key role is assigned to specific preventive vaccination [7-10]. The main criteria for the effectiveness of vaccination are the following:

1) formation of protective immunity in the majority of vaccinated individuals in the herd;

2) production of specific antibodies and T-lymphocytes directed at significant epitopes of infectious agents;

3) formation of a long-lasting immune memory for the corresponding antigens [11-13].

In the farms of the Udmurt Republic, parainfluenza-3, respiratory syncytial infection, infectious rhinotracheitis, viral diarrhea is the most common. For the prevention of these cattle diseases, the inactivated combined vaccine Kombovak is used (produced by the SPA "Narvak", city of Moscow), and in farms that are disadvantaged by pasteurellosis Kombovak R. Despite the widespread use of this vaccine, an ambiguous situation develops in the farms of the UR and the percentage of ARVI incidence is extremely variable. Such changes in the spread of respiratory diseases are associated with differences in feeding, in veterinary and sanitary conditions of keeping animals, in the poor condition of farms for parasitic and bacterial diseases [14-15]. These circumstances have a direct impact on the formation of post-vaccination immunity in each individual and collective immunity in general. The issue of the formation of collective immunity for breeding enterprises is especially relevant [16].

Currently, there are disputes over the choice of a vaccination scheme, because in the instructions for the vaccine, the developers recommend 2 vaccination schemes:

- scheme No. 1 - vaccination of pregnant animals twice, respectively, 60-50 days before calving and the second time - after 21 days.

- scheme No. 2 - vaccination of the entire livestock of animals older than one year every 6 months twice with an interval of 21 days.

The schemes differ in the duration of the inter-vaccination period. Obviously, when using scheme No. 1, it will be much larger. This can reduce the material and labor costs for carrying out specific prevention of ARVI. Therefore, the purpose of the work was to evaluate the effectiveness of double (with an interval of 21 days) immunization with the Kombovak-R vaccine 60-50 days before calving in an industrial livestock complex.

\section{Materials and methods of research}

The work was carried out in the period from 2019 to 2020 in the conditions of a livestock complex located in the Uvinsky district of the Udmurt Republic.

The company specializes in milk and meat production. He is engaged in the cultivation of Black-and-white cattle and has been a breeding reproducer since 2016.

During the period of the work, 1,383 heads of cattle were under observation, vaccinated with an inactivated combined vaccine against infectious rhinotracheitis, parainfluenza-3, respiratory syncytial infection, viral diarrhea and pasteurellosis of cattle - Kombovak-R. 
The animals were vaccinated according to the following scheme:

- primary vaccination of calves aged 10-14 days at a dose of $2 \mathrm{ml}$ intramuscularly and secondary vaccination after 21 days at the age of 30-35 days.

- revaccination after 6 months, i.e. at the age of 7 months at a dose of $3 \mathrm{ml}$.

- next, heifers of covering age (13-14 months), claves are not revaccinated because at the age of 12 months they are handed over for slaughter.

- cows and heifers primary vaccination 2 months before calving and secondary vaccination after 21 days (on average 30-35 days before calving).

Laboratory tests were carried out in the BI UR "Udmurt Veterinary Diagnostic Center" in the city of Izhevsk and LLC "Independent Veterinary Laboratory "Chance-Bio" in the city of Moscow. Determination of immunity intensity and retrospective serological diagnosis of ARVI was carried out by examining paired blood serum samples.

The vaccination effectiveness was evaluated by the titer of serum antibodies to infectious the viruses of rhinotracheitis (IRT), viral diarrhea - mucosal disease (VD-MD), parainfluenza-3 (PI-3), respiratory syncytial (PS) and adenovirus (AVI) infections of cattle using a "Complex PCR test system for determining the level of antibodies to viral respiratory diseases of cattle".

Blood serum samples were taken from clinically healthy cows at the 6th month of pregnancy, i.e. at the end of the inter-vaccination period.

To study the presence and duration of colostral immunity against ARVI, blood samples were taken from unvaccinated calves with a live weight of 50-55 kg at the age of 17-18 days and after 21 days, respectively.

Blood samples from newborn calves that did not receive the first portion of colostrum were taken from the jugular vein into vacuum tubes within one hour after birth. Blood samples of newborn calves were taken within 2 weeks. The choice fell on clinically healthy calves obtained as a result of uncomplicated calving.

Before each blood collection, all animals were subjected to a clinical examination, including thermometry, visual examination of visible mucous membranes, determination of habitus, presence/absence of rumination, the number of scar contractions.

\section{Research results}

Considering the importance of feeding and maintenance conditions for the formation of general immunological resistance and the formation of post-vaccination immunity, a survey of the farm was conducted. The following was established: the cattle population was placed in 8 livestock buildings: two buildings for tethered cows, a building for loose keeping, a maternity ward and a dispensary for calves 0-2 months, a building for fattening animals, a yard for keeping heifers of breeding age and a calf house for calves 3-6 months, a quarantine department where animals are placed for quarantine before breeding sale.

There are 1,653 heads of cattle, including 644 heads of cows, 116 heads of heifers, 131 heads of fattening steers, 173 heads of heifers up to 6 months of age, 139 heads of steers up to 6 months of age, 144 heads of heifers older than 6 months of age, 122 heads of heifers older than 1 year, 184 heads of heifers of breeding age. A herd of cattle is completed at the expense of its own reproduction. The indicators of herd productivity for the last 5 years are shown in Table 1.

Table 1. Quantitative and qualitative indicators of herd productivity.

\begin{tabular}{|l|l|l|l|l|l|}
\hline Indicators & 2016 & 2017 & 2018 & 2019 & 2020 \\
\hline Cattle total, head & 1465 & 1574 & 1636 & 1646 & 1653 \\
\hline including cows, head & 534 & 536 & 636 & 637 & 644 \\
\hline
\end{tabular}




\begin{tabular}{|l|l|l|l|l|l|}
\hline Average milk yield from one cow, kg & 6297 & 6249 & 6179 & 6250 & 6260 \\
\hline Fat content in milk, \% & 3.51 & 3.56 & 3.60 & 3.51 & 3.52 \\
\hline Protein content in milk, \% & 3.03 & 3.02 & 3.02 & 3.09 & 3.05 \\
\hline Live calves obtained total, head & 661 & 693 & 794 & 742 & 761 \\
\hline including from cows, head & 468 & 519 & 559 & 541 & 573 \\
\hline Calved heifers, head & 193 & 174 & 235 & 201 & 188 \\
\hline Output of live calves per 100 cows, \% & 88 & 97 & 88 & 85 & 89 \\
\hline Cows dropped out per year, heads & 51 & 58 & 81 & 96 & 84 \\
\hline
\end{tabular}

According to the table, every year there is an increase in the total number of livestock. Quantitative and qualitative indicators remain stable.

Cows and heifers are kept in standard premises with tether and without it. Young animals on rearing - in adapted cages, in groups of 10-15 animals. The maternity ward includes 200 places for cows and heifers, as well as individual cages for calves from 0 to 2 months. In the first 3 days, calves receive colostrum directly from their mother, and from the 7th day they get accustomed to feeding from a bucket. The calves are kept on a litter. The manure from the cages to the corridor is removed manually. Cows are kept on wooden floors with a sawdust litter. Calving takes place directly in the stall. Manure removal takes place by an auger conveyor.

Group drinking pans are used for watering cows. For feeding, a year-round silage-haylage type of feeding is used. Depending on the milk productivity and physiological state, animals receive fodder, cake, salt, chalk, premixes. On the loose keeping and CDF No. 1, the feed is prepared in the form of monofeed.

There are walking yards near each room, where cows walk for 1.5-2 hours after morning milking.

The density of the animals does not exceed the required standards, the principle of "empty-occupied" is observed, disinfection is carried out regularly. Wet disinfection of livestock premises is carried out 1 time a month with a $0.5 \%$ solution of Ligrocide or Virocide. The quality of disinfection is studied in the BI UR "Mozhginsk Interdistrict Veterinary Laboratory" Uvinsk laboratory. The sanitary condition of the premises is satisfactory.

All livestock by age categories are subjected to preventive vaccinations and treatments according to the plan of anti-epizootic measures.

Cattle is tested allergic to tuberculosis twice a year. No reacting animals were detected. Once a year, cows and heifers are examined for brucellosis and leukemia. Vaccinations are carried out against anthrax, leptospirosis, rabies, infectious nodular dermatitis, ARVI.

The survey noted that the conditions for feeding and keeping animals of all sex and age groups are satisfactory.

Analyzing the technological scheme of preventive treatments, and in particular vaccination against acute respiratory viral infections with the Kombovak vaccine, it was found that the gap between vaccinations is 10 months or more, which depends on the duration of the service period. Table 2 shows examples of vaccination of cows according to the scheme adopted on the farm.

Table 2. Terms of vaccination with the Kombovak-R vaccine.

\begin{tabular}{|l|l|l|l|l|l|}
\hline $\begin{array}{l}\text { Number } \\
\text { of animal }\end{array}$ & $\begin{array}{l}\text { Date of } \\
\text { vaccination } \\
\text { Kombovak }\end{array}$ & $\begin{array}{l}\text { Calving } \\
\text { date }\end{array}$ & $\begin{array}{l}\text { Service- } \\
\text { period }\end{array}$ & $\begin{array}{l}\text { Approximate } \\
\text { dates of the } \\
\text { next } \\
\text { vaccination }\end{array}$ & $\begin{array}{l}\text { Interval between } \\
\text { vaccinations } \\
\text { ex post }\end{array}$ \\
\hline 3117 & $\begin{array}{l}23.09 .2020 \text { and } \\
15.10 .2020\end{array}$ & 20.11 .2020 & 62 days & 16.08 .2021 & $\sim 10$ months \\
\hline
\end{tabular}




\begin{tabular}{|l|l|l|l|l|l|}
\hline 4156 & $\begin{array}{l}23.09 .2020 \text { and } \\
15.10 .2020\end{array}$ & 18.11 .2020 & 81 days & 7.09 .2021 & $\sim 10.5$ months \\
\hline
\end{tabular}

According to Table 2, cows were vaccinated against IRT, PI-3, VD, and RSI initially on 23.09.2020, revaccination was carried out on 15.10.2020. Given the timing of calving and the service-period, it turns out that approximately the next vaccination will be only in 10 10.5 months. This is if the insemination was fruitful from the first or from the second time. The longer the duration of the service-period, the longer the interval between vaccinations, and it accordingly exceeds 6 months. If the service-period is 120 days, the vaccination will take place once a year.

Given the large difference in the duration of the inter-vaccination period with different vaccination schemes, it can be assumed that the intensity of immunity will be different.

To study the intensity of immunity to ARVI at the end of the inter-vaccination period, blood samples were taken by the method of paired serums from 5 cows aged 4 to 6 years, with a 6 month pregnancy, a live weight of 550-600 kg. The results of the studies are shown in Table 3.

Table 3. The intensity of immunity against ARVI in cows.

\begin{tabular}{|c|l|l|l|l|l|l|l|l|l|}
\hline $\begin{array}{l}\text { N } \\
\text { o. }\end{array}$ & $\begin{array}{c}\text { Number } \\
\text { of animal }\end{array}$ & \multicolumn{2}{|c|}{ PI-3 } & \multicolumn{2}{c|}{ IRT } & \multicolumn{2}{c|}{ VD } & \multicolumn{2}{c|}{ RSI } \\
\cline { 2 - 11 } & & $\begin{array}{c}1 \\
\text { batch }\end{array}$ & 2 batch & 1 batch & 2 batch & 1 batch & 2 batch & 1 batch & 2 batch \\
\hline 1 & 3117 & $1: 128$ & $1: 256$ & $1: 128$ & $1: 128$ & $1: 64$ & neg & $1: 32$ & $1: 16$ \\
\hline 2 & 4818 & $1: 256$ & $1: 256$ & $1: 256$ & $1: 256$ & $1: 256$ & $1: 32$ & $1: 64$ & $1: 64$ \\
\hline 3 & 4802 & $1: 64$ & $1: 512$ & $1: 16$ & $1: 64$ & $1: 128$ & neg & $1: 32$ & $1: 16$ \\
\hline 4 & 3459 & $1: 256$ & $1: 512$ & $1: 256$ & $1: 256$ & $1: 256$ & $1: 128$ & $1: 128$ & $1: 128$ \\
\hline 5 & 4156 & neg & neg & $1: 256$ & $1: 256$ & $1: 256$ & $1: 128$ & $1: 16$ & $1: 128$ \\
\hline
\end{tabular}

In the data of the table, the following points call attention to themselves:

1.One cow out of 5 (with the individual number 4802) had a complete absence of antibodies to the pathogen of Parainfluenza-3. At the same time, studies have shown an 8fold increase in the titer.

2. The presence of antibodies to the etiological agent of IRT was revealed in all animals. Once again, a cow with the individual number 4802 has a seroconversion with a 4-fold increase in the antibody titer.

3. Antibodies to the causative agent of viral diarrhea were found in all the studied animals.

4. A study for the presence of antibodies to the respiratory syncytial infection virus showed their presence in all cows. Nevertheless, an 8-fold increase in titer was detected in a cow with the individual number 4156 .

5. Against the general background, relatively low antibody titers for all infections in a cow with an individual number 3117 call attention.

A more detailed examination of the clinical condition of animals with detected seroconversion did not reveal any signs of the disease and changes in the general condition, which is reflected in the act of epizootological examination (investigation) of the causes of detection of antibodies to the IRT virus and PI-3 in the study of blood from cows, dated August 9, 2019.

Considering the serological instability among pregnant animals and the possibility of intrauterine infection in case of field strain of the virus in the herd, it was decided to conduct studies for the presence of antibodies to pathogens of acute respiratory viral infections in unvaccinated calves. The results of the serological study are shown in Table 4. 
Table 4. Immunity stress to ARVI in calves.

\begin{tabular}{|c|c|c|c|c|c|c|c|c|c|}
\hline \multirow[t]{2}{*}{$\begin{array}{l}\mathrm{N} \\
\mathrm{o}\end{array}$} & \multirow[t]{2}{*}{$\begin{array}{l}\text { Animal } \\
\text { number }\end{array}$} & \multicolumn{2}{|c|}{$\begin{array}{l}\text { PI-3 (AT to PI-3 } \\
\text { virus) }\end{array}$} & \multicolumn{2}{|c|}{$\begin{array}{l}\text { IRT (AT to IRT } \\
\text { virus) }\end{array}$} & \multicolumn{2}{|c|}{$\begin{array}{l}\text { VD (AT to VD } \\
\text { virus) }\end{array}$} & \multicolumn{2}{|c|}{$\begin{array}{l}\text { RSI (AT to RSI } \\
\text { virus) }\end{array}$} \\
\hline & & 1 batch & 2 batch & 1 batch & 2 batch & 1 batch & 2 batch & 1 batch & 2 batch \\
\hline 1 & 18516 & $1: 256$ & $1: 512$ & $1: 256$ & $1: 256$ & $1: 16$ & $1: 64$ & neg & $1: 32$ \\
\hline 2 & 18515 & $1: 256$ & $1: 256$ & $1: 256$ & $1: 256$ & $1: 32$ & $1: 32$ & neg & $1: 16$ \\
\hline 3 & 6228 & $1: 128$ & $1: 512$ & $1: 256$ & $1: 256$ & $1: 128$ & neg & $1: 64$ & $1: 16$ \\
\hline 4 & 6230 & $1: 64$ & $1: 512$ & $1: 256$ & $1: 256$ & $1: 16$ & $1: 16$ & $1: 16$ & neg \\
\hline 5 & 6231 & $1: 512$ & $1: 512$ & $1: 256$ & $1: 256$ & $1: 128$ & $1: 64$ & $1: 128$ & $1: 128$ \\
\hline
\end{tabular}

In the data of the examination, the following points call attention to themselves:

1. The presence of antibodies in all calves was established for parainfluenza-3. Of these, a 4-fold increase in the antibody titer was detected in 2 samples: calves with individual numbers 6228 and 6230 .

2. Determination of the titer of specific antibodies to the infectious rhinotracheitis virus showed the presence of antibodies in all samples, no increase in the titer was detected.

3. Viral diarrhea was detected in all calves. At the same time, one sample with a 4-fold increase in the antibody titer: a calf with the number 18516.

4. The lowest titers of antibodies were registered to the respiratory syncytial infection virus.

A detailed examination of the clinical condition of these calves did not reveal any signs of the disease and changes in the general condition, which is reflected in the act of epizootological examination dated August 9, 2019.

To study the possibility of intrauterine infection with ARVI, 10 samples of blood sera from newborn calves that have not yet had time to receive the first portion of colostrum were selected. The results of the study are shown in Tables 5-8.

Table 5. The presence of AT to the parainfluenza-3 virus in the blood serum of newborn calves.

\begin{tabular}{|c|c|c|c|c|c|}
\hline No. & $\begin{array}{l}\text { Type } \\
\text { animal }\end{array}$ & Sample ID & $\begin{array}{l}\text { Animal } \\
\text { inventory } \\
\text { number }\end{array}$ & $\begin{array}{l}\text { Value of the } \\
\text { calculated } \\
\text { coefficient (K)* }\end{array}$ & Conclusion \\
\hline 1 & Cattle & PL8162536 & 3048 & 0.005 & negative \\
\hline 2 & Cattle & PL8163926 & 5326 & 0.003 & negative \\
\hline 3 & Cattle & PL8162107 & 3887 & 0.010 & negative \\
\hline 4 & Cattle & PL8168018 & 536 & 0.023 & negative \\
\hline 5 & Cattle & PL8167774 & 3476 & 0.036 & negative \\
\hline 6 & Cattle & PL8168648 & 4463 & 0.001 & negative \\
\hline 7 & Cattle & PL8163192 & 3048 & 0.011 & negative \\
\hline 8 & Cattle & PL8168414 & 13147 & 0.001 & negative \\
\hline 9 & Cattle & PL8161812 & 5338 & 0.003 & negative \\
\hline 10 & Cattle & PL8163923 & 5316 & 0.003 & negative \\
\hline
\end{tabular}

* $\mathrm{K}<0.1$ - negative; $0.1<\mathrm{K}<0.2$ - doubtful; $0.2<\mathrm{K}<0.4$ - positive $(+) ; 0.4<\mathrm{K}<0.6$ - positive $(++)$; $0.6<\mathrm{K}<0.8$ - positive $(+++) ; \mathrm{K}>0.8$ - positive $(++++)$.

Table 6. The presence of AT to the IRT virus in the blood serum of newborn calves.

\begin{tabular}{|c|c|c|c|c|c|}
\hline No. & $\begin{array}{l}\text { Type of } \\
\text { animal }\end{array}$ & Sample ID & $\begin{array}{l}\text { Animal } \\
\text { inventory } \\
\text { number }\end{array}$ & $\begin{array}{l}\text { Percentage of } \\
\text { inhibition (PI)* }\end{array}$ & Conclusion \\
\hline 1 & Cattle & PL8162536 & 3048 & 5.85 & negative \\
\hline 2 & Cattle & PL8163926 & 5326 & 0.66 & negative \\
\hline
\end{tabular}




\begin{tabular}{|c|c|c|c|c|c|}
\hline 3 & Cattle & PL8162107 & 3887 & 6.79 & negative \\
\hline 4 & Cattle & PL8168018 & 536 & 28.06 & negative \\
\hline 5 & Cattle & PL8167774 & 3476 & 21.83 & negative \\
\hline 6 & Cattle & PL8168648 & 4463 & 7.02 & negative \\
\hline 7 & Cattle & PL8163192 & 3048 & 8.30 & negative \\
\hline 8 & Cattle & PL8168414 & 13147 & 6.17 & negative \\
\hline 9 & Cattle & PL8161812 & 5338 & 4.35 & negative \\
\hline 10 & Cattle & PL8163923 & 5316 & 1.13 & negative \\
\hline
\end{tabular}

* $\mathrm{PI}<40 \%$ - negative; $\mathrm{PI}>40 \%$ - positive.

Table 7. The presence of AT to the VD virus in the blood serum of newborn calves.

\begin{tabular}{|c|l|l|l|c|c|}
\hline No. & $\begin{array}{l}\text { Type } \\
\text { animal }\end{array}$ & Sample ID & $\begin{array}{l}\text { Animal } \\
\text { inventory } \\
\text { number }\end{array}$ & $\begin{array}{l}\text { Percentage of } \\
\text { inhibition (PI)* }\end{array}$ & Conclusion \\
\hline 1 & Cattle & PL8162536 & 3048 & 2.51 & negative \\
\hline 2 & Cattle & PL8163926 & 5326 & 9.45 & negative \\
\hline 3 & Cattle & PL8162107 & 3887 & 0.01 & negative \\
\hline 4 & Cattle & PL8168018 & 536 & 8.19 & negative \\
\hline 5 & Cattle & PL8167774 & 3476 & 18.37 & negative \\
\hline 6 & Cattle & PL8168648 & 4463 & 11.22 & negative \\
\hline 7 & Cattle & PL8163192 & 3048 & 0.22 & negative \\
\hline 8 & Cattle & PL8168414 & 13147 & 5.86 & negative \\
\hline 9 & Cattle & PL8161812 & 5338 & 0.79 & negative \\
\hline 10 & Cattle & PL8163923 & 5316 & 3.31 & negative \\
\hline
\end{tabular}

* $\mathrm{PI}<50 \%$ - negative; $50 \%<\mathrm{PI}<80 \%$ - weakly positive (+); $\mathrm{PI}>80 \%$ - positive (++).

Table 8. The presence of AT to the RSI virus in the blood serum of newborn calves.

\begin{tabular}{|c|l|l|l|l|l|}
\hline No. & $\begin{array}{l}\text { Type of } \\
\text { animal }\end{array}$ & Sample ID & $\begin{array}{l}\text { Animal } \\
\text { inventory } \\
\text { number }\end{array}$ & $\begin{array}{l}\text { Value of the } \\
\text { calculated } \\
\text { coefficient } \\
\text { S/P\%* }\end{array}$ & Conclusion \\
\hline 1 & Cattle & PL8162536 & 3048 & 1.09 & negative \\
\hline 2 & Cattle & PL8163926 & 5326 & 1.07 & negative \\
\hline 3 & Cattle & PL8162107 & 3887 & 0.89 & negative \\
\hline 4 & Cattle & PL8168018 & 536 & 1.08 & negative \\
\hline 5 & Cattle & PL8167774 & 3476 & 0.91 & negative \\
\hline 6 & Cattle & PL8168648 & 4463 & 0.56 & negative \\
\hline 7 & Cattle & PL8163192 & 3048 & 0.92 & negative \\
\hline 8 & Cattle & PL8168414 & 13147 & 0.91 & negative \\
\hline 9 & Cattle & PL8161812 & 5338 & 1.34 & negative \\
\hline 10 & Cattle & PL8163923 & 5316 & 0.79 & negative \\
\hline
\end{tabular}

* $\mathrm{S} / \mathrm{P} \%<20$ - negative; $\mathrm{S} / \mathrm{P} \%>20$ - positive.

Thus, the conducted studies have shown that antibodies to PI-3, IRT, VD, and RSI were not detected, consequently, intrauterine infection does not occur. This fact further confirms the need for timely drinking of colostrum in the first 1-2 hours after birth, because only with colostrum the calf will receive the immunoglobulins necessary for the formation of full-fledged colostral immunity. 


\section{Discussion}

When studying the preservation of post-vaccination immunity in cows, it was found that only two out of five studied animals have a protective level of antibodies to acute respiratory viral infections by the end of the inter-vaccination period. The critical moment is the appearance of animals with seroconversion by 4 or more times. Despite the absence of clinical signs of diseases, this indicates the serological instability of the herd and the presence of risks of outbreaks of respiratory diseases, which dictates the need to adjust the technological map and the vaccination scheme.

Serological screening of calves showed that antibodies to the pathogens of IRT, VD, RSI and PI-3 were determined in all samples. nevertheless, the titers of antibodies to ARVI pathogens differed significantly. The presence of seroconversion in some samples by 4 or more times in the complete absence of clinical signs of diseases is most likely due to the age of the animals - 17/18 and 38/39 days. Along with the residual amount of colostral antibodies, the production of their own begins, which in the absence of vaccination may indicate the circulation of field virus strains in the herd.

\section{Conclusion}

When only down-calving cows are immunized with the Kombovak-R vaccine, the appearance of animals with both a low antibody titer and a significant seroconversion is noted in the herd, which is the result of a gap between vaccinations that far exceeds 6 months. Considering the results obtained, it was decided to introduce changes to the technological map and carry out vaccination of Kombovak-R 2 times a year, regardless of the pregnancy duration.

Analyzing the results obtained, conclusions were made:

1. When using scheme No. 1 for vaccination, the duration of the inter-vaccination period is 10 months or more, which reduces the tension of collective immunity to acute respiratory viral infections.

2. The most stable indicators of colostral immunity were revealed to the infectious rhinotracheitis virus.

3. The smallest number of protective antibodies in the blood serum of calves was detected to the VD and RSI viruses.

4. Seroconversion of 4 or more times to the Parainfluenza-3 virus and VD in unvaccinated calves indicates the circulation of field strains of infectious agents in the herd.

Based on the conclusions made, proposals for the production were formulated:

1. To make a choice of immunization schemes with the Kombovak and Kombovak-R vaccine, considering the level of immunity stress.

2. For the timely and complete formation of colostral immunity against acute respiratory viral infections in cattle, to give colostrum to calves in the first 1-2 hours of life.

\section{References}

1. A.G. Glotov, T.I. Glotova, S.V. Koteneva, A.V. Nefedchenko, O.V. Semyonova, Veterinary medicine 3, 3-8 (2019) DOI:10.30896/0042-4846.2019.22.3.03-08

2. Bernadette Earleya, Katie Tiernan, Catherine Duffy, Amanda Dunn, Sinead Waters, Steven Morrison, Mark McGee, Research in Veterinary Science, 43-51 (2018)

3. V.V. Evstifeev, M.N. Konnov, F.M. Khusainov, G.I. Khusainova, I.R. Akbashev, Veterinary medicine 10, 19-25 (2019) DOI:10.30896/0042-4846.2019.22.10.19-25 
4. A.G. Glotov, T.I. Glotova, Veterinary medicine 6, 10-13 (2019) DOI:10.30896/00424846.2019.22.5.10-13

5. A.G. Glotov, T.I. Glotova, O.V. Semenova, A.A. Nikonova, Veterinary medicine, 1, 39 (2019) DOI:10.30896/0042-4846.2019.22.1.03-09

6. Roberto A. Palomares, Shonda M. Marley, M. Daniel Givens, Rodrigo A. Gallardo, Kenny V. Brock, Theriogenology, 1184-1195 (2013) DOI.org/10.1016/j.theriogenology.2013.02.017.

7. M.D.Givens, B.W. Newcomer, Animal Health Research Reviews 16(1), 78-82 (2015) DOI: $10.1017 / \mathrm{S} 1466252315000043$

8. Ben M. Hause, Lucas Huntimer, Shollie Falkenberg, Jamie Henningson, Kelly Lechtenberg, Tom Halbur, Veterinary Microbiology 47-53 (2017) DOI.org/10.1016/j.vetmic.2016.12.024.

9. Benjamin W. Newcomer, Manuel F. Chamorro, Paul H. Walz, Veterinary Microbiology, 78-83 (2017) DOI.org/10.1016/j.vetmic.2017.04.003

10. Michel R. Rey, Michael Undi, Juan C. Rodriguez-Lecompte, Tomy Joseph, Jason Morrison, Alexander Yitbarek, Karin Wittenberg, Robert Tremblay, Gary H. Crow, Kim H. Ominski, The Veterinary Journal, 235-238 (2013) DOI.org/10.1016/j.tvj1.2013.06.019.

11. J.S. Salt, S.J. Thevasagayam A. Wiseman, A.R. Peters, The Veterinary Journal, 616-626 (2007) DOI.org/10.1016/j.tvj1.2006.10.007

12. Paul H. Walz, Kay P. Riddell, Benjamin W. Newcomer, John D. Neill, Shollie M. Falkenberg, Victor S. Cortese, Daniel W. Scruggs, Thomas H. Short, Vaccine, 38533860 (2018) DOI.org/10.1016/j.vaccine.2018.04.005

13. JohnEllis, Debra Mattick, Linda Smith, Ryan Brady, EmilioTrigo, Vaccine, 3784-3792 (2010) DOI.org/10.1016/j.vaccine.2010.03.043

14. E.S. Klimova, M.E. Mkrtchyan, E.V. Maximova, E.A. Mikheeva, International Bulletin of Veterinary Medicine 3, 20-29 (2020) DOI: 10.17238/issn2072-2419.2020.3.24.

15. Christopher McMullen, Trevor W. Alexander, Karin Orsel, Edouard Timsit, Veterinary Microbiology, (2020) DOI.org/10.1016/j.vetmic.2020.108826.

16. A.F. Shulyak, G.N. Velichko, M.V. Nosova, Veterinary medicine 12, 16-20 (2019) DOI:10.30896/0042-4846.2019.22.12.16-20 